\title{
Induction and elimination of bulky benzo[a]pyrene-related DNA adducts and 8-oxodGuo in mussels Mytilus galloprovincialis exposed in vivo to B[a]P-contaminated feed
}

\author{
F. Akcha' ${ }^{1}$ T. Burgeot ${ }^{2}$, H. Budzinski ${ }^{1}$, A. Pfohl-Leszkowicz ${ }^{3}$, J.-F. Narbonne ${ }^{1}$ \\ ${ }^{1}$ Laboratoire de Physico- et Toxicochimie des Systèmes Naturels, UPRESA 5472 CNRS, Université de Bordeaux 1, \\ Avenue des Facultés, 33405 Talence, France \\ ${ }^{2}$ IFREMER, Laboratoire des Polluants chimiques, Rue de l'Ile d'Yeu, 44300 Nantes Cedex, France \\ ${ }^{3}$ ENSAT, Laboratoire de Toxicologie et de Sécurité Alimentaire, Avenue de l'Agrobiopôle, BP 107, Auzeville Tolosane, \\ 31326 Castanet-Tolosane Cedex, France
}

\begin{abstract}
With the aim of developing biomarkers of polycyclic aromatic hydrocarbon (PAH) genotoxicity for biomonitoring of the marine environment, the formation of DNA adducts and oxidative DNA damage was studied in the sentinel organism Mytilus. Mussels M. galloprovincialis were ex-

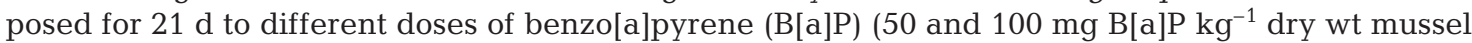
$\mathrm{d}^{-1}$ ) via trophic intake. The kinetics of $\mathrm{B}[\mathrm{a}] \mathrm{P}$ concentration in whole mussel tissues was determined in both groups, and a dose-response study was conducted for both gill B[a]P-related DNA adducts and 8-oxo-7, 8-dihydro-2'-deoxyguanosine (8-oxodGuo) formation in gill and digestive gland DNA. Exposure was followed by a $10 \mathrm{~d}$ depuration period to study mussel recovery. Although B[a]P was absorbed and bioaccumulated to very high concentrations (>300 mg B $[\mathrm{a}] \mathrm{P} \mathrm{kg}{ }^{-1}$ dry wt mussel), plateau values were not reached in either assay group. Regardless of the exposure dose of $\mathrm{B}[\mathrm{a}] \mathrm{P}$, several bulky DNA adducts were induced in the typical PAH diagonal radioactive zone. For both doses, positive correlations were found between total DNA adduct level and both exposure time and B[a]P concentration in whole mussel tissues. DNA repair during depuration differed among the B[a]P-induced DNA adducts. B[a]P exposure had no effect on gill 8-oxodGuo levels, but led to a significant dosedependent increase in the number of oxidative lesions in mussel digestive gland DNA. The decrease with depuration in digestive gland 8-oxodGuo levels to control values was indicative of the mussels' ability to recover from oxidative DNA damage.
\end{abstract}

KEY WORDS: B[a]P $\cdot$ Mussel $\cdot$ DNA adducts $\cdot 8$-oxodGuo $\cdot$ DNA repair

Resale or republication not permitted without written consent of the publisher

\section{INTRODUCTION}

The presence of various pollutants in the different compartments of the marine environment (Neff 1984, La Rocca et al. 1996, Penry \& Weston 1998, Regoli 1998) may cause pathologies, including cancer, in

*E-mail: f.akcha@lptc.u-bordeaux.fr living organisms (Gardner 1993). In mollusks, a causeeffect relationship has been clearly demonstrated in field and laboratory studies between exposure to pollutants (polycyclic aromatic hydrocarbons [PAHs], chlorinated hydrocarbons, polychlorinated biphenyls [PCBs], heavy metals) and the development of histopathological lesions and tumors (Yevich et al. 1987, Auffret 1988, Gardner et al. 1991, 1992). More extensive studies in fish have extended the theory of 
mammalian chemical carcinogenesis (Barrett 1992) to marine organisms. In benthic fish, positive correlation has been found in situ between the development of hepatic neoplasms and PAH concentration in sediment (Landahl et al. 1990, Myers et al. 1994). Cancerous lesions have been induced in the laboratory following exposure to some PAHs, including benzo[a]pyrene (B[a]P) (Hendricks et al. 1985, Fong et al. 1993), and $\mathrm{K}$-ras oncogenes have been activated in induced neoplasms (Wirgin et al. 1989, MacMahon et al. 1990, Fong et al. 1993).

As PAHs are predominant pollutants in the environment, PAH-induced DNA damage has been extensively studied in vertebrates for the model compound B[a]P (Colapietro et al. 1993, Chen et al. 1996, De Vries et al. 1997). As causes of mutations and potential initiators of the multi-stage cancer process, DNA adducts (Jelinsky et al. 1995, Shukla et al. 1999) and DNA oxidized bases (Kuchino et al. 1987, Cheng et al. 1992), e.g. 8-oxo-7, 8-dihydro-2'-deoxyguanosine (8-oxodGuo), have been proposed respectively as biomarkers of genotoxicity (La \& Swenberg 1996) and genotoxicity/ oxidative stress in vertebrates (Shigenaga \& Ames 1991, Simic 1994).

The present study was conducted in the context of a research program on $\mathrm{B}[\mathrm{a}] \mathrm{P}$-induced DNA damage involving the formation of bulky DNA adducts and 8-oxodGuo in Mytilus species used as sentinel organisms for biomonitoring of the marine environment (Goldberg 1975, Viarengo \& Canesi 1991). The purpose of the program was to determine whether these types of DNA damage can be used as biomarkers of PAH genotoxicity in mussels.

Initially, in this program, a B[a]P exposure model was developed for the mussel Mytilus galloprovincialis (Akcha et al. 1999). As mussel contamination occurs in the field via filter-feeding activity, exposure via trophic supply was selected for our experiments. The suitability of this model for DNA damage analysis was validated by confirming B[a]P bioavailability for the exposed organisms and covalent binding of $\left[{ }^{3} \mathrm{H}\right]-\mathrm{B}[\mathrm{a}] \mathrm{P}$ to gill and digestive gland DNA (Akcha et al. 1999).

As demonstrated by the nuclease P1-enhanced ${ }^{32} \mathrm{P}$ postlabeling assay, exposure of mussels to $\mathrm{B}[\mathrm{a}] \mathrm{P}$ resulted in the formation of bulky $\mathrm{B}[\mathrm{a}] \mathrm{P}$-related DNA adducts in both the digestive gland (Akcha et al. 2000) and gill tissues (Akcha et al. in press), confirming the ability of mussels to metabolize $\mathrm{B}[\mathrm{a}] \mathrm{P}$ to reactive metabolites (Michel et al. 1995).

Using our model of exposure, several enzymatic biomarkers were measured in B[a]P-exposed mussels (Akcha et al. 2000). Among them, a significant increase and decrease respectively in catalase and DT-diaphorase activities were considered to indicate increased production of reactive oxygen species (ROS), qualifying this model for the study of the effects of B[a]P exposure on 8-oxodGuo formation in the mussel (Akcha et al. in press).

The present work focused on a dose-response study of both gill $\mathrm{B}[\mathrm{a}] \mathrm{P}$-related DNA adducts, and gill and digestive gland 8-oxodGuo formation. Mussels were exposed to B[a]P for $21 \mathrm{~d}$, followed by a $10 \mathrm{~d}$ depuration period to assess their ability to recover from genotoxic damage. With regard to our previous findings, results presented in this paper were discussed for the possible application of both biomarkers in mussels for the biomonitoring of the marine environment.

\section{MATERIAL AND METHODS}

Animal treatment. Specimens of the mussel Mytilus galloprovincialis $(7.0 \pm 0.5 \mathrm{~cm}$ length, $1.1 \pm 0.3 \mathrm{~g}$ dry wt), purchased at La Teste (Atlantic Ocean, France) from Les Viviers d'Aquitaine, originated from Rya de la Rosa (Gallice, Spain) and were kept in wet docks before being sold. In the laboratory, 3 groups of 122 individuals were formed and kept in glass aquariums filled with $35 \%$ seawater. Water (1 1 individual ${ }^{-1}$ ) was pumped from the Bay of Arcachon and oxygenated by a common air-bubbler system. The water temperature was stabilized at $18^{\circ} \mathrm{C}$ by an air conditioner. Mussels were fed daily (24 mg equivalent dry wt individual ${ }^{-1}$ ) with Marine Liquifry (Interpet), a commercial nutritive solution for marine invertebrates. Feed was distributed to each aquarium $8 \mathrm{~h} \mathrm{~d}^{-1}$ by a peristaltic pump. During the rest of the day, water was filtered through an active charcoal (Actikool) column by an external pump (Rena, $91 \mathrm{~min}^{-1}$ ). Thus, water was never renewed during the experiment.

After 1 wk of acclimation, mussels were contaminated with $\mathrm{B}[\mathrm{a}] \mathrm{P}$ via their feed supply. Every morning, the feed of 2 experimental groups was freshly contaminated with $\mathrm{B}[\mathrm{a}] \mathrm{P}$ to reach a concentration of 2.08 and $4.16 \mu \mathrm{g}$ B[a]P $\mathrm{mg}^{-1}$ Marine Liquifry in order to expose mussels to a daily theoretical and individual dose of respectively 50 and $100 \mathrm{mg} \mathrm{B}[\mathrm{a}] \mathrm{P} \mathrm{kg} \mathrm{kg}^{-1}$ dry wt mussel. The third experimental group was used as a control. The lowest $\mathrm{B}[\mathrm{a}] \mathrm{P}$ dose was representative of the highest total PAH content (Michel 1983) recorded in Mytilus galloprovincialis (area of Nice-La Reserve, $54.4 \mathrm{mg} \mathrm{kg}^{-1}$ dry wt mussel) from the French Mediterranean coasts (RNO 1995). Considering the relatively low adduct levels induced in mussels with this dose (Akcha et al. 2000, in press), a second higher dose (100 $\mathrm{mg} \mathrm{kg}^{-1}$ dry wt mussel) was used for experimental purposes. As feed was given as a solution, these doses correspond also to $\mathrm{B}[\mathrm{a}] \mathrm{P}$ water concentrations of 50 and $100 \mathrm{ppb}$. 
The contamination experiment lasted $21 \mathrm{~d}$ and was followed by a $10 \mathrm{~d}$ depuration period. Samples were collected in each aquarium at Days 3, 10 and 21 of exposure and at Days 5 and 10 of depuration. Day 0 samples were collected at the end of the acclimation period by taking animals from all 3 tanks. On the basis of our previous experiments, an estimated mortality of $10 \%$ was assumed for the sampling program. At each sampling point, 12 individuals were collected for gas chromatography/mass spectrometry (GC/MS) analysis of $\mathrm{B}[\mathrm{a}] \mathrm{P}$ concentration in whole mussel tissues. Three pools of 3 individual tissues were also sampled for measurement of both bulky DNA adducts in gills and 8-oxodGuo in gill and digestive gland DNA.

Chemical analysis of whole mussel tissues. $\mathrm{B}[\mathrm{a}] \mathrm{P}$ concentration in whole mussel tissues was determined as previously described in Akcha et al. (2000). The total organic extract of each freeze-dried sample was obtained by focused microwave-assisted extraction and fractionated by normal-phase high performance liquid chromatography (HPLC) for separate collection of saturated and aromatic compounds. Aromatic fractions were subjected to gas chromatography (HP5890 series II gas chromatograph) and mass spectrometry analysis (HP5972 MSD mass spectrometer) under the selected ion monitoring mode using the molecular ions of the studied PAH (electron impact at $70 \mathrm{eV}, 2000 \mathrm{~V}$, 1 scan $\mathrm{s}^{-1}$ ). Quantification of $\mathrm{B}[\mathrm{a}] \mathrm{P}$ in each sample was performed according to perdeuterated $\mathrm{B}[\mathrm{a}] \mathrm{Pd}_{12}$ (MSD Isotopes). The response factor was calculated with standard solutions.

8-oxodGuo measurement. DNA extraction: The method applied was derived from that of Helbock et al. (1998). Typically, 100 to $150 \mathrm{mg}$ of tissue per sample were homogenized in $2 \mathrm{ml}$ buffer A (320 mM sucrose, $5 \mathrm{mM} \mathrm{MgCl}_{2}, 10 \mathrm{mM}$ Tris- $\mathrm{HCl}, 0.1 \mathrm{mM}$ deferoxamine mesylate [Sigma-Aldrich Chemical], $1 \%$ triton X-100, $\mathrm{pH} 7.5$ ) and centrifuged at $1500 \times g$ for $10 \mathrm{~min}$ at $4^{\circ} \mathrm{C}$. The supernatant was then discarded and the pellet washed with $2 \mathrm{ml}$ buffer A. Following centrifugation for $10 \mathrm{~min}$ at $1500 \times g$, the pellet was recovered and resuspended in $600 \mu \mathrm{l} 5 \mathrm{mM}$ EDTA-Na, $10 \mathrm{mM}$ Tris$\mathrm{HCl}, 0.15 \mathrm{mM}$ deferoxamine mesylate $(\mathrm{pH}$ 8). After addition of $35 \mu \mathrm{l} 10 \%$ SDS, RNA digestion was performed by incubation with $60 \mu \mathrm{g}$ RNAse A (SigmaAldrich Chemical) and 10 U RNAse T1 (Roche Molecular Biochemicals) for $15 \mathrm{~min}$ at $50^{\circ} \mathrm{C}$. Protein digestion was carried out by incubation with $600 \mu \mathrm{g}$ protease (Sigma-Aldrich Chemical) for $1 \mathrm{~h}$ at $37^{\circ} \mathrm{C}$. The sample was then centrifuged at $5000 \times g$ for $15 \mathrm{~min}$ at $4^{\circ} \mathrm{C}$, and the supernatant was recovered in a $5 \mathrm{ml}$ sterile tube. Following addition of a $1.2 \mathrm{ml}$ sodium iodide solution (20 mM EDTA-Na $, 7.6 \mathrm{M} \mathrm{NaI}, 40 \mathrm{mM}$ Tris- $\mathrm{HCl}$, $0.3 \mathrm{mM}$ deferoxamine mesylate, $\mathrm{pH}$ 8) and $2 \mathrm{ml}$ isopropanol, the tube was centrifuged for $15 \mathrm{~min}$ at
$5000 \times g$. The pellet was then recovered and resuspended in $2 \mathrm{ml} 40 \%$ isopropanol. Following centrifugation, the pellet was washed in $2 \mathrm{ml} 70 \%$ ethanol and resuspended in $100 \mu \mathrm{l} 0.1 \mathrm{mM}$ deferoxamine mesylate. Samples were stored at $-20^{\circ} \mathrm{C}$ prior to digestion.

HPLC/electrochemical detection assay: The $100 \mu \mathrm{l}$ DNA solution was entirely digested to deoxyribonucle-

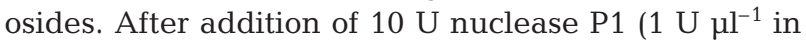
$300 \mathrm{mM}$ sodium acetate, $1 \mathrm{mM} \mathrm{ZnSO}_{4}$, pH 5.5) (Roche Molecular Biochemicals) and 1 U alkaline phosphatase (Sigma-Aldrich Chemical), samples were incubated for $90 \mathrm{~min}$ at $37^{\circ} \mathrm{C}$. Proteins were precipitated with $100 \mu \mathrm{l}$ chloroform. Then the samples were centrifuged at $10000 \times g$ for $5 \mathrm{~min}$, and the supernatants recovered for injection.

8-oxodGuo determination was carried out by HPLC (System Gold 118, Beckman) coupled to electrochemical detection (Kontron 405). Separation of 8-oxodGuo from 2'-deoxyribonucleosides was performed on an Ultrasphere C18 pre-column (Interchrom, ODS, $45 \mathrm{~mm}$ $\times 4.6 \mathrm{~mm}, 5 \mu \mathrm{m}$ ) and an Uptisphere column (Interchrom, ODB, $250 \mathrm{~mm} \times 4.6 \mathrm{~mm}, 5 \mu \mathrm{m})$. Elution was performed in isocratic mode using a mobile phase composed of methanol $10 \%$, citric acid $10 \mathrm{mM}$, sodium acetate $25 \mathrm{mM}$, sodium hydroxide $30 \mathrm{mM}$ and acetic acid $10 \mathrm{mM}$. The elution flow rate was set at $1 \mathrm{ml} \mathrm{min}^{-1}$. The detection sensitivity of the electrochemical detector was $1 \mathrm{nA} \mathrm{V}^{-1}$ for an oxidation potential of $650 \mathrm{mV}$. 8-oxodGuo quantification was done in accordance with a calibration curve previously obtained with known pmole amounts of authentic 8-oxodGuo (SigmaAldrich Chemical). For standard expression in number of 8-oxodGuo residues per $10^{5} \mathrm{dGuo}$, deoxyguanosine was also quantified by coupling a UV detector (System Gold 166, Beckman) at the output of the HPLC column. The UV apparatus was set at a wavelength of $260 \mathrm{~nm}$. A calibration curve was also obtained for this compound in the nmole range. For the conditions described, the retention times of both 8-oxodGuo and dGuo were around 20 and 15 min respectively.

Measurement of bulky B[a]P-related DNA adducts. DNA extraction: Mussel gill DNA was prepared as described by Genevois et al. (1998) and qualitative and quantitative analysis of DNA samples was performed by UV spectrophotometry $\left(1 \mathrm{OD}=50 \mu \mathrm{g} \mathrm{DNA} \mathrm{ml}^{-1}\right.$, $\lambda_{\max }=258$ to $260 \mathrm{~nm}$ ) (Genesys5, Bioblock). For each DNA sample, an aliquot of $7 \mu \mathrm{g}$ DNA was prepared and stored at $-80^{\circ} \mathrm{C}$ prior to use.

${ }^{32} \boldsymbol{P}$ post-labeling assay: Each DNA sample $(7 \mu \mathrm{g})$ was analyzed for its adduct content by applying the ${ }^{32} \mathrm{P}$ post-labeling technique as described in Genevois et al. (1998). Multidimensional migration of each sample was conducted on home-made polyethylenimine thin layer chromatography (TLC) plates. Migration of each sample was performed in a solvent system composed 
of (D1) $2.3 \mathrm{M} \mathrm{NaH}_{2} \mathrm{PO}_{4}$, pH 5.7 (16 h migration), after transfer contact (D2) 7.7 M urea, 4.8 M lithium formate, $\mathrm{pH} 3.5$ in the same direction as D1 (pre-migration with Milli-Q water, $3 \mathrm{~h}$ migration), (D3) $1 \mathrm{M}$ lithium chloride, $8 \mathrm{M}$ urea, $0.5 \mathrm{M}$ Tris, $\mathrm{pH} 8$ in perpendicular direction to D2 (2 h 30 min migration), and (D4) $1.7 \mathrm{M}$ $\mathrm{NaH}_{2} \mathrm{PO}_{4}, \mathrm{pH}$, in the same direction as D3 (premigration with MilliQ water, at least $2 \mathrm{~h}$ migration).

Autoradiography of the TLC plates allowed qualitative analysis of the bulky B[a]P-related DNA adducts of each sample. Quantification of radioactive spots was performed by an AMBIS Radioanalytical Scanning System (Lablogic), and the results were expressed as the number of adducts per $10^{8}$ normal nucleotides (relative adduct labeling, RAL). Control samples were analyzed at Day 0 and Day 21 to confirm the absence of unrelated B[a]P-DNA adducts.

Statistical analysis. Time-course data for B[a]P concentration in mussels from both assay groups were analyzed by calculating mathematical regression and $\mathrm{B}[\mathrm{a}] \mathrm{P}$ uptake rates.

Data for 8-oxodGuo and DNA adducts were analyzed at each sampling point by 1-way ANOVA (Statistica Inc. Software), taking the exposure dose of B[a]P as a factor. Variance homogeneity had been previously checked by the Hartley test, and a Newman Keuls test was per-
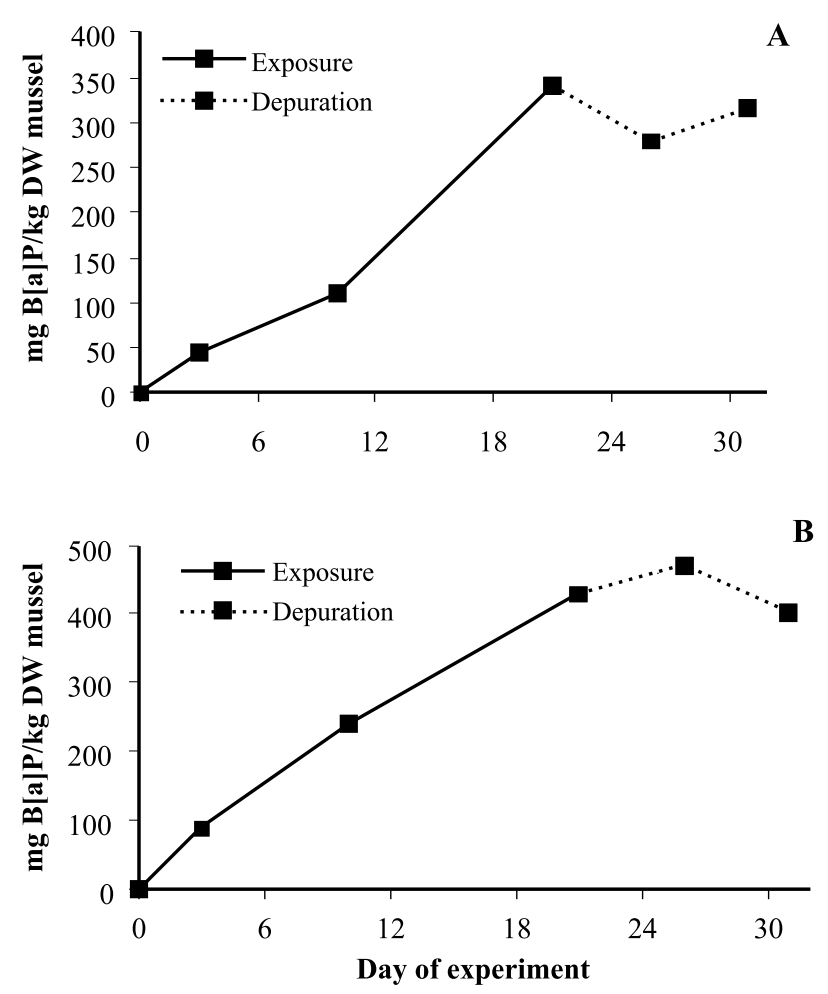

formed each time an effect was found to be significant. To assess the effect of depuration, Student's $t$-tests were performed when relevant. For both 8-oxodGuo and DNA adduct levels, correlations with $\mathrm{B}[\mathrm{a}] \mathrm{P}$ exposure time and whole mussel tissue $\mathrm{B}[\mathrm{a}] \mathrm{P}$ concentration were determined by calculating a mathematical regression. The mathematical models proposed in this paper were the simplest ones that significantly explained the observed value dispersion. Each calculated mean was characterized by its standard deviation value.

\section{RESULTS}

\section{$\mathrm{B}[\mathrm{a}] \mathrm{P}$ bioaccumulation}

For both tested doses, a linear increase with exposure time in $\mathrm{B}[\mathrm{a}] \mathrm{P}$ concentration was recorded in whole mussel tissues (Fig. 1). In both experimental groups, the $\mathrm{B}$ [a]P concentrations reached at the end of the $21 \mathrm{~d}$ of exposure were quite high: 340.39 and $428.63 \mathrm{mg}$ $\mathrm{kg}^{-1}$ dry wt for groups exposed respectively to 50 and $100 \mathrm{mg} \mathrm{B}[\mathrm{a}] \mathrm{P} \mathrm{kg}^{-1}$ dry wt mussel $\mathrm{d}^{-1}$. Regarding the calculated rates of $\mathrm{B}[\mathrm{a}] \mathrm{P}$ uptake (Table 1), a decrease was observed between Days 10 and 21 of exposure in the higher dose group. Except for lower uptake be-
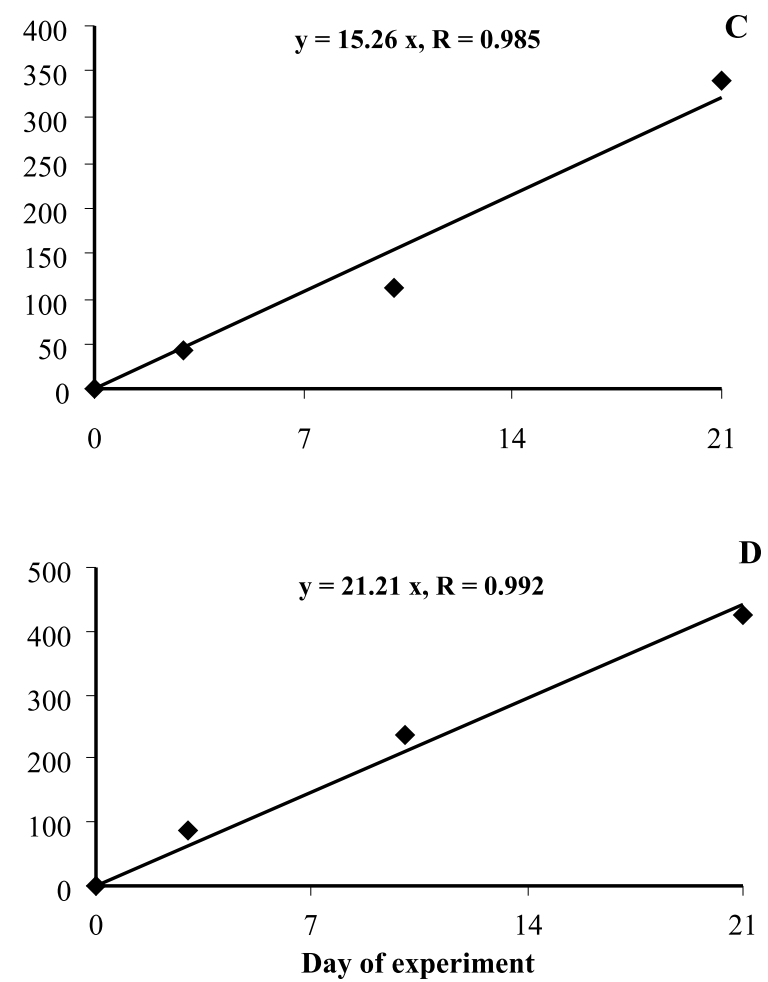

Fig. 1. B[a]P concentration kinetics in whole mussel tissues following exposure to (A) 50 and (B) $\left.100 \mathrm{mg} \mathrm{B}^{\mathrm{a}}\right] \mathrm{P} \mathrm{kg}^{-1} \mathrm{dry}_{\mathrm{wt}} \mathrm{mussel}$ $\mathrm{d}^{-1}$ (concentrations in unexposed animals close to 0 are represented by the solid line). Increase in B[a]P concentration with time of exposure follows a linear mathematical model in mussels exposed to (C) 50 and (D) $100 \mathrm{mg} \mathrm{kg}^{-1}$ dry wt mussel 
Table 1. Uptake rates calculated from B[a]P bioaccumulation kinetics of both assay groups

\begin{tabular}{|c|c|c|}
\hline Experimental group & $\begin{array}{l}\text { Exposure } \\
\text { period } \\
\text { (Day) }\end{array}$ & $\begin{array}{c}\text { Uptake rate } \\
\left(\mathrm{mg} \text { B }[\mathrm{a}] \mathrm{Pg}^{-1}\right. \\
\left.\text { dry wt mussel d }{ }^{-1}\right)\end{array}$ \\
\hline $\begin{array}{l}50 \mathrm{mg} \mathrm{kg}^{-1} \\
\text { dry wt mussel d }{ }^{-1}\end{array}$ & $\begin{array}{r}0-3 \\
3-10 \\
10-21 \\
0-21\end{array}$ & $\begin{array}{r}14.57 \\
9.64 \\
20.84 \\
16.20\end{array}$ \\
\hline $\begin{array}{l}100 \mathrm{mg} \mathrm{kg}^{-1} \\
\text { dry wt mussel d }\end{array}$ & $\begin{array}{r}0-3 \\
3-10 \\
10-21 \\
0-21\end{array}$ & $\begin{array}{l}28.86 \\
21.99 \\
17.10 \\
20.41\end{array}$ \\
\hline
\end{tabular}

tween Days 3 and 10 of exposure, no similar decrease was measured in half-dosed mussels at the end of the exposure period.

Although a lack of standard deviation values for chemical data did not allow the statistical significance of the results to be tested, decrease in $\mathrm{B}[\mathrm{a}] \mathrm{P}$ concentration after the depuration period did not seem obvious in either assay group.

\section{8-oxodGuo measurement}

Raw data on 8-oxodGuo measurement in both gill and digestive gland DNA are shown in Fig. 2.

\section{Gill DNA}

Regardless of the B[a]P dose and exposure time tested, no effect of B[a]P on 8-oxodGuo level was detected in mussel gill DNA ( $p>0.05$ at each sampling point).

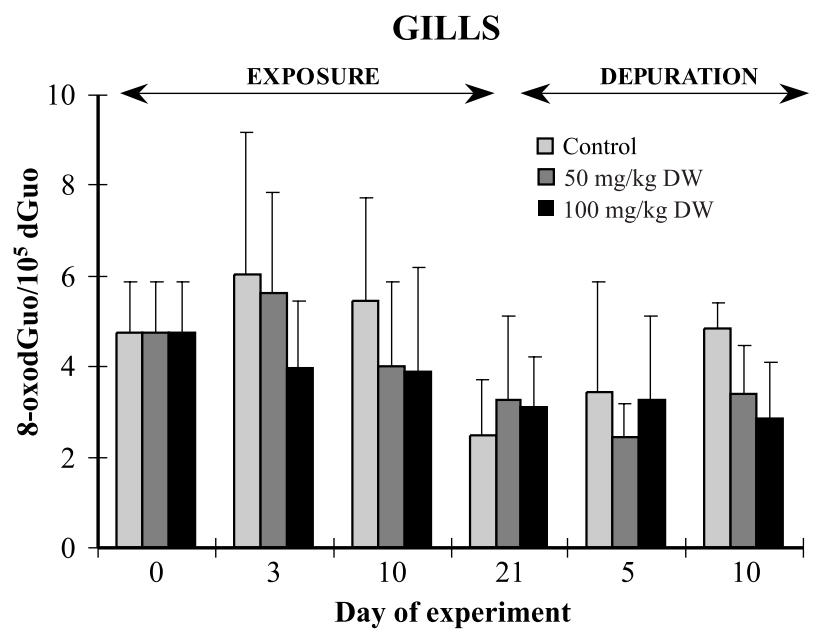

Digestive gland DNA

A significant effect of $\mathrm{B}[\mathrm{a}] \mathrm{P}$ on the 8-oxodGuo level of mussel digestive gland DNA was recorded in both assay groups. B[a]P exposure produced a significant dose-dependent increase in the number of lesions. For mussels exposed to $50 \mathrm{mg}$ B [a] $\mathrm{P} \mathrm{kg}^{-1}$ dry wt mussel $\mathrm{d}^{-1}$, the increase was significant from Day 10 of exposure ( $p=0.02$ and $p<0.001$ at Days 10 and 21 respectively), whereas those exposed to $100 \mathrm{mg}$ B[a]P $\mathrm{kg}^{-1}$ dry wt mussel $\mathrm{d}^{-1}$ showed increased levels only at this date $(p=0.02)$. Following the depuration period, 8-oxodGuo levels of mussels exposed to the lower B[a]P dose decreased significantly $(0.01<\mathrm{p}<0.001)$, reaching control values as early as Day 5 of depuration ( $p>0.05)$.

In mussels exposed to $50 \mathrm{mg}$ B[a]P $\mathrm{kg}^{-1}$ dry wt mussel $\mathrm{d}^{-1}$, mean 8-oxodGuo level increased linearly both with exposure time (8-oxodGuo $/ 10^{5} \mathrm{dGuo}=$ $0.55 \times d+6.98, d f=10, R=0.882, p<0.001)$ and $\mathrm{B}$ [a]P concentration in whole mussel tissue (Fig. 3). For mussels exposed to a double B[a]P dose, the mean 8-oxodGuo level was also correlated both with time (8-oxodGuo $/ 10^{5} \mathrm{dGuo}=-0.01 \times \mathrm{d}^{3}+0.141 \times \mathrm{d}^{2}-$ $0.69 \mathrm{~d}+8.30, \mathrm{df}=10, \mathrm{R}=0.651,0.02<\mathrm{p}<0.01)$ and $\mathrm{B}$ [a]P concentration (Fig. 3), but in a more complex manner. For the higher dose, the relationship between 8-oxodGuo level and mussel B[a]P content showed 3 possibilities: (1) for exposure levels corresponding to a $\mathrm{B}[\mathrm{a}] \mathrm{P}$ mussel content lower than $100 \mathrm{mg}$ $\mathrm{kg}^{-1}$ dry wt mussel, digestive gland 8-oxodGuo level remained unchanged; (2) for higher exposure levels corresponding to a $\mathrm{B}[\mathrm{a}] \mathrm{P}$ mussel content between approximately 100 and $340 \mathrm{mg} \mathrm{kg}^{-1}$ dry wt mussel, the 8-oxodGuo level of mussel digestive gland was significantly increased; (3) above this B[a]P mussel content limit, the 8-oxodGuo level decreased signifi-

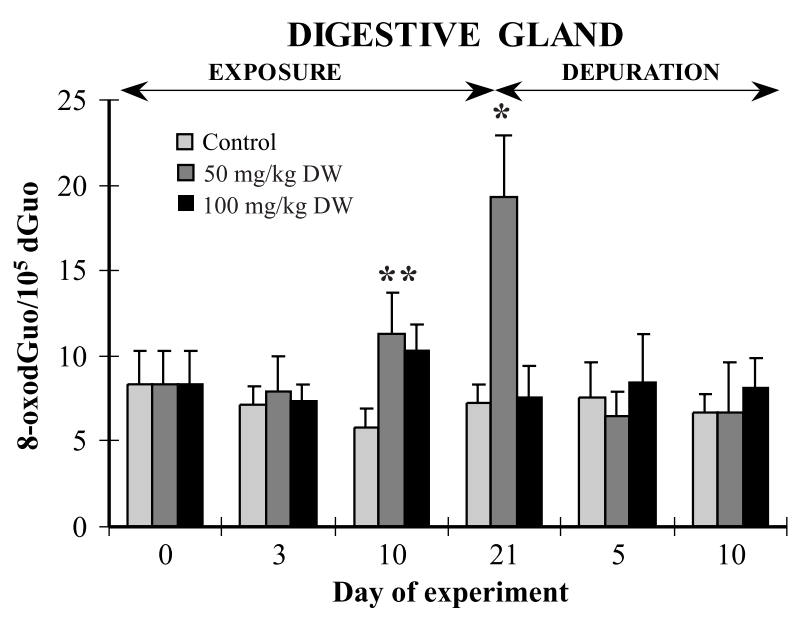

Fig. 2. Mean 8-oxodGuo level $(\mathrm{n}=3)$ measured in mussel gill and digestive gland DNA by HPLC-ED assay. ${ }^{*}$ Statistically significant $(\mathrm{p}<0.05)$ 

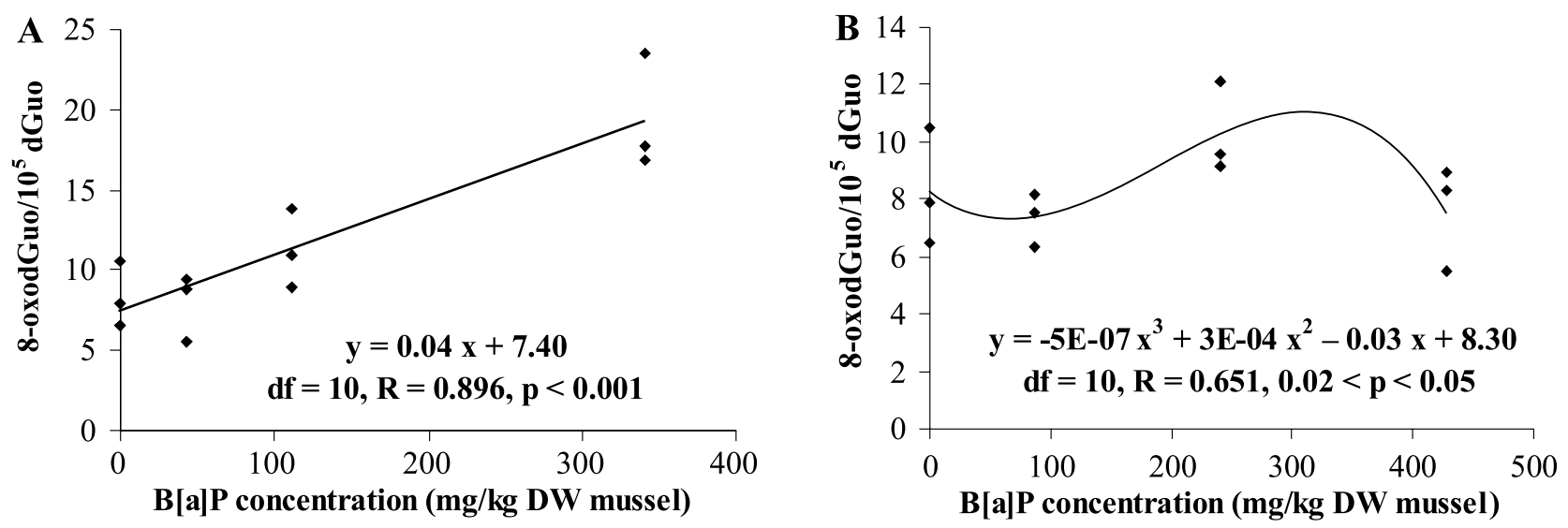

Fig. 3. Relationship between 8-oxodGuo level of digestive gland DNA ( $\mathrm{n}=3$ ) and whole mussel tissue $\mathrm{B}[\mathrm{a}] \mathrm{P}$ concentration in animals exposed to (A) 50 and (B) $100 \mathrm{mg} \mathrm{B}[\mathrm{a}] \mathrm{P} \mathrm{kg}^{-1}$ dry wt mussel

cantly, reaching control values for concentrations above $400 \mathrm{mg} \mathrm{kg}^{-1}$ dry wt mussel.

\section{B[a]P-related DNA adducts in mussel gill DNA}

Raw data on gill DNA adduct levels are shown in Fig. 4. Although no adducts were observed in control samples, several distinct spots in the diagonal radioactive zone were recorded on TLC plates from exposed mussels (Fig. 5). Adducts 1, 2 and 6 were predominant in both groups, appearing as early as Day 3 in mussels exposed to $100 \mathrm{mg}$ B[a]P $\mathrm{kg}^{-1}$ dry wt mussel $\mathrm{d}^{-1}$. Adducts 1 and 2 were the only ones still present in the latter group at the end of the $10 \mathrm{~d}$ depuration period, whereas some additional faint spots remained in mussels exposed to a half-dose.

No differences between the 2 tested doses were found for total or individual adduct levels during the

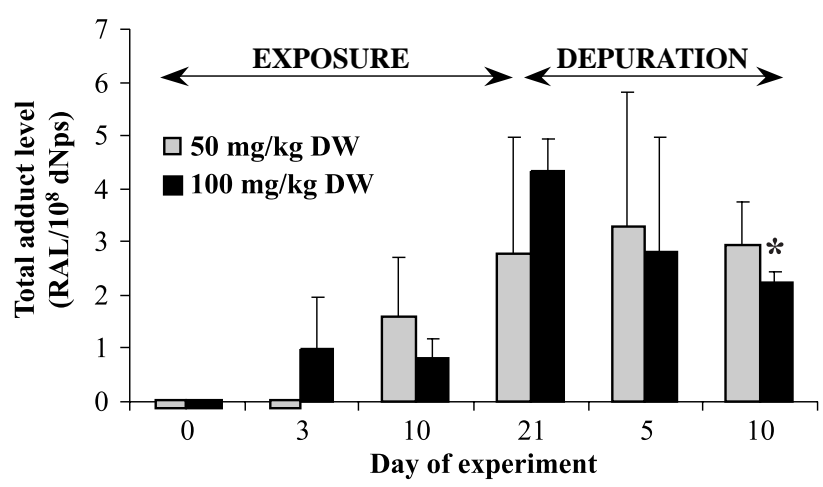

Fig. 4. Mean total level $(\mathrm{n}=3)$ of B[a]P-related DNA adducts in mussel gills. Linear increase in DNA adduct level with time of exposure in both assay group $(0.02<\mathrm{p}<0.05$ and $0.001<$ $\mathrm{p}<0.01$ for mussels exposed to 50 and $100 \mathrm{mg} \mathrm{kg}^{-1}$ dry wt mussel respectively). ${ }^{*}$ Significant decrease in adduct level with depuration $(\mathrm{p}<0.05)$ exposure and depuration periods $(\mathrm{p}>0.05)$. In both groups, total DNA adduct level increased linearly with $\mathrm{B}$ [a]P exposure time: RAL $/ 10^{8} \mathrm{dNps}=0.14 \times \mathrm{d}-0.11$, $\mathrm{df}=6, \mathrm{R}=0.788,0.02<\mathrm{p}<0.05$ and $\mathrm{RAL} / 10^{8} \mathrm{dNps}=$ $0.19 \times \mathrm{d}-0.10, \mathrm{df}=6, \mathrm{R}=0.904,0.001<\mathrm{p}<0.01$ for the groups exposed respectively to 50 and $100 \mathrm{mg} \mathrm{B[a]P}$ $\mathrm{kg}^{-1}$ dry wt mussel $\mathrm{d}^{-1}$. For both groups, a positive correlation between total DNA adduct level and whole mussel tissue $\mathrm{B}$ [a]P concentration was also found: RAL $\times 10^{8} \mathrm{dNps}=0.01 \times \mathrm{B}[\mathrm{a}] \mathrm{P}$ concentration $\left(\mathrm{mg} \mathrm{kg}^{-1} \mathrm{dry}\right.$ $\mathrm{wt})+0.05, \mathrm{df}=6, \mathrm{R}=0.760,0.02<\mathrm{p}<0.05$ and $\mathrm{RAL} \times$ $10^{8} \mathrm{dNps}=0.01 \times \mathrm{B}[\mathrm{a}] \mathrm{P}$ concentration $\left(\mathrm{mg} \mathrm{kg}^{-1}\right.$ dry wt) -0.21 , df $=6, R=0.879,0.01<p<0.001$ for groups exposed respectively to 50 and $\left.100 \mathrm{mg} \mathrm{B}^{\mathrm{a}} \mathrm{a}\right] \mathrm{P} \mathrm{kg}^{-1} \mathrm{dry}$ wt mussel $\mathrm{d}^{-1}$.

No significant decreases in the level of total DNA adducts were observed in the group exposed to $50 \mathrm{mg}$ $\mathrm{B}$ [a]P $\mathrm{kg}^{-1}$ dry wt mussel $\mathrm{d}^{-1}$ after $5(t=0.22$, df $=2$, $\mathrm{p}>0.05)$ and $10(t=0.11, \mathrm{df}=2, \mathrm{p}>0.05)$ days of depuration. For mussels exposed to a double B[a]P dose, the decrease was not significant at Day 5 of depuration $(t=0.95$, df $=2, \mathrm{p}>0.05)$, but became significant at Day $10(t=4.53, \mathrm{df}=2, \mathrm{p}<0.05)$.

\section{DISCUSSION}

\section{$\mathrm{B}[\mathrm{a}] \mathrm{P}$ bioaccumulation in mussel tissues}

The results in this study confirm our previous findings (Akcha et al. 2000) concerning the absorption and bioaccumulation of feed-incorporated $\mathrm{B}[\mathrm{a}] \mathrm{P}$ to very high concentrations in mussels. As already reported in the literature, mussels can accumulate organic micropollutants such as PAHs via the water column, in sediment or by trophic intake (Narbonne et al. 1992, Eertman et al. 1995, Björk \& Gilek 1996). In the present 

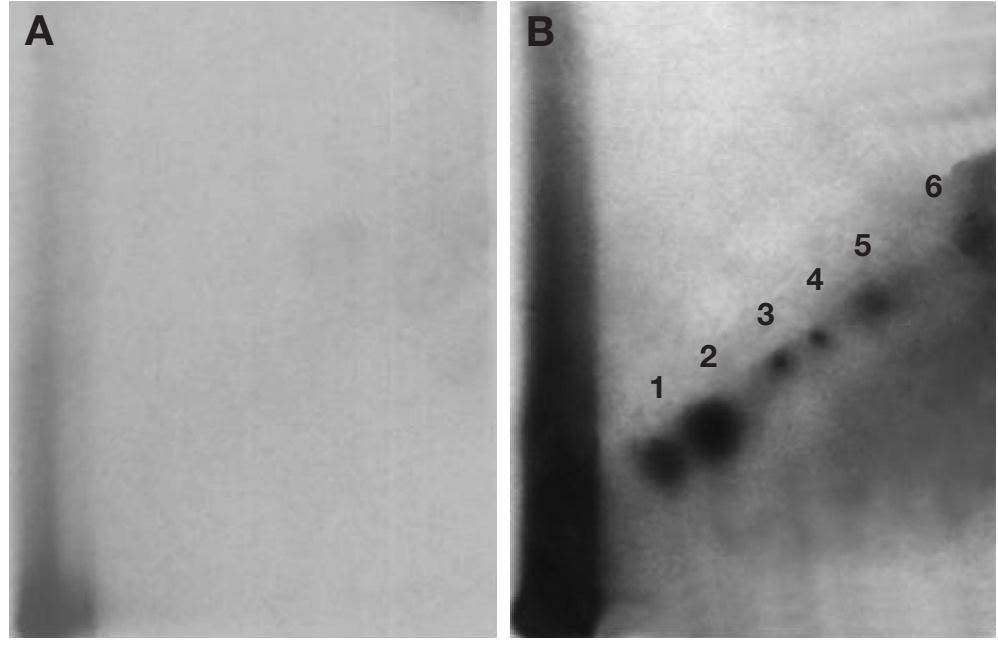

Fig. 5. DNA adduct pattern of B[a]P-exposed mussels. (A) Control gill DNA; (B) typical pattern of gill DNA adducts (adducts 1 to 6) observed from Day 10 of exposure in mussels daily exposed to 50 and $100 \mathrm{mg} \mathrm{B}[\mathrm{a}] \mathrm{P} \mathrm{kg} \mathrm{kg}^{-1}$ dry wt mussel

that mussel ability to bioconcentrate B[a]P approaches saturation. Although our preliminary study showed that the digestive gland had a high concentration of $\mathrm{B}[\mathrm{a}] \mathrm{P}$ because of its primordial role in biotransformation (Akcha et al. 1999), unmetabolized $\mathrm{B}[\mathrm{a}] \mathrm{P}$ is thought to be mainly bioconcentrated in mussel lipid-rich compartments such as the mantle and gonads. As a decrease in mussel dry wt was previously observed with our model (Akcha et al. 2000), it is possible that saturation was expressed prematurely because of a decrease in the lipid content available for storage. Another possible explanation is a survival-adaptive response of mussel to $\mathrm{B}[\mathrm{a}] \mathrm{P}$ toxicity through a reduction in the filtration rate or by shell closure. However, it is noteworthy that the $\mathrm{B}[\mathrm{a}] \mathrm{P}$ concentrations recorded in this study were well above the given mussel tissue concentration producing a $50 \%$ reduction of

experiment, $\mathrm{B}[\mathrm{a}] \mathrm{P}$ concentrations in mussels were nearly 10 times as high as the total PAH concentrations reported in these organisms by the French biomonitoring network (Réseau National d'Observation, RNO). In its surveillance of French coastal pollution, the RNO has been measuring the concentrations of several representative pollutants in bivalves since 1979. Hence, mean total PAH concentration in mussels ranged from less than $2 \mathrm{mg}$ kg dry wt mussel (Mont Saint Michel Bay) to $54.4 \mathrm{mg}$ kg dry wt mussel (Cannes-Villefranche area) during the 1979 to 1993 sampling period (RNO 1995). Although the concentrations recorded in mussels during the present experiment were higher than those ordinarily found in the marine environment due to the aim of the study to induce DNA adducts on a short experimental period, plateau values were not reached in either assay group. The increase in concentration with exposure time fitted a linear mathematical model in both cases, as demonstrated in a field transplantation study for lower PAH concentrations (Mix et al. 1981).

As the second dose tested in our experiment (100 mg $\mathrm{B}$ [a]P $\mathrm{kg}^{-1}$ dry wt mussel $\mathrm{d}^{-1}$ ) was twice as high as the first one, the absolute final $\mathrm{B}[\mathrm{a}] \mathrm{P}$ concentration in mussels could have been expected to be twice as high. Yet, despite an uptake rate at least twice as high as that of half dosed mussels, B[a]P uptake decreased from Day 10 of exposure in mussels exposed to a double dose. This decrease accounted for the relatively minor difference in $\mathrm{B}[\mathrm{a}] \mathrm{P}$ concentrations in mussels between the 2 tested doses at the end of the exposure period. Despite the time-related validation of a linear regression model in this group, such a decrease may indicate the clearance rate (16 $\mathrm{mg} \mathrm{B}[\mathrm{a}] \mathrm{P} \mathrm{kg}^{-1}$ dry wt mussel) (Eertman et al. 1995).

Because of a lack of standard deviation values for our chemical data, the effect of depuration on B[a]P concentration could not be assessed statistically. Nevertheless, B[a]P depuration did not appear to be efficient. These results are not consistent with published data (Dunn \& Stich 1976, Mix et al. 1981, Björk \& Gilek 1996, Moy \& Walday 1996) or with our previous findings showing that exposure of mussels for $13 \mathrm{~d}$ to a mixture of $\left[\mathrm{H}^{3}\right] \mathrm{B}[\mathrm{a}] \mathrm{P} / \mathrm{B}[\mathrm{a}] \mathrm{P}$ (50 $\mathrm{mg} \mathrm{kg}^{-1}$ dry wt mussel $\mathrm{d}^{-1}$ ) led with depuration to a decrease of respectively 73 and $32 \%$ in digestive gland and gill tissues (Akcha et al. 1999). In the latter study, although no decrease in $\mathrm{B}[\mathrm{a}] \mathrm{P}$ concentration was noted in the mantle, $\mathrm{B}[\mathrm{a}] \mathrm{P}$ depuration in whole mussel tissues was however assumed to be efficient taking into account tissue weight distribution. As a matter of fact, B[a]P concentration in whole mussel tissues decreased in another study by 19 and $35 \%$ respectively following a $4 \mathrm{~d}$ depuration period in mussels exposed to the same dose for 22 and 25 d (Akcha et al. 2000). In the present study, a decrease in mussel filtration activity may have been responsible for the low depuration observed.

\section{Effect of B[a]P exposure on 8-oxodGuo level}

Among the contaminants present in the marine environment, some PAHs, and nitroaromatic and agrochemical compounds (lindane, paraquat) have been identified as prooxidants in vertebrates (Livingstone et al. 1990). Thus, increased reactive oxygen species (ROS) 
production in aquatic organisms may be a mediator of toxicity for some environmental pollutants (Livingstone et al. 1990, Livingstone 1991).

An increase in digestive gland 8-oxodGuo level after $\mathrm{B}[\mathrm{a}] \mathrm{P}$ exposure is concordant with the knowledge of mussel free radical biology. The induction of hydroxyl radical production $\left(\mathrm{OH}^{\cdot}\right)$, as ultimate ROS of both Fenton and Haber-Weiss reactions, has been studied in the mussel due to its strong reactivity with cellular macromolecules, particularly DNA. Except for singlet oxygen $\left(\mathrm{O}_{2}{ }^{1}\right), \mathrm{OH}^{*}$ is the only ROS that can cause DNA damage directly by producing base oxidation (Shigenaga \& Ames 1991, Cadet et al. 1997). Increased OH· production in mussels has been demonstrated in vitro in digestive gland microsomes with the model quinone, menadione (Livingstone et al. 1989, Sjölin \& Livingstone 1997), the nitroaromatic compound nitrofurantoin (Garcia Martinez et al. 1995), and several PAH quinones including 1,6-, 3,6- and 6,12-B[a]P quinones (Garcia Martinez \& Livingstone 1995, Sjölin \& Livingstone 1997). Although ROS production induced by PAH exposure has never been directly demonstrated in vivo in the mussel, some effects of oxidative stress have been observed in vivo in this organism either in terms of lipid peroxidation (Moore 1988, Livingstone et al. 1990) or DNA strand break induction (Mitchelmore \& Chipman 1998). In the mussel, the variations induced by PAH exposure in cellular antioxidant defenses are also considered to result from an increase in ROS production (Ribera et al. 1991, Solé et al. 1994).

As $\mathrm{B}[\mathrm{a}] \mathrm{P}$ is metabolized in vivo predominantly to quinones in mussels (Michel et al. 1995), the increase in digestive gland 8-oxodGuo level by $\mathrm{B}[\mathrm{a}] \mathrm{P}$ exposure is mainly explained by higher ROS production through redox cycling of quinones. As a matter of fact, the mussel digestive gland displays a vertebrate-like cytochrome P450 reductase activity (Livingstone et al. 1990, Michel et al. 1993) that may catalyze quinone reduction to semiquinone radicals with subsequent ROS production. As antioxidant defenses are greater in the digestive gland than gills (Livingstone \& Pipe 1992), the absence of $\mathrm{B}[\mathrm{a}] \mathrm{P}$ effect on the gill 8-oxodGuo level observed in our experiment may have been due to lower ROS production in this tissue related to lower phase I activities (Stegeman 1985). However, this result is in contrast with the reported effect of waterborne $\mathrm{B}[\mathrm{a}] \mathrm{P}$ exposure (0.5 to $1000 \mathrm{ppb} \mathrm{B}[\mathrm{a}] \mathrm{P})$ on the level of mussel gill 8-oxodGuo (Canova et al. 1998). In the latter study, significantly higher 8-oxodGuo levels were observed following $48 \mathrm{~h}$ exposure to 5,50 and $100 \mathrm{ppb} \mathrm{B}[\mathrm{a}] \mathrm{P}$ and $72 \mathrm{~h}$ exposure to $5,50,100$, $1000 \mathrm{ppb} \mathrm{B}[\mathrm{a}] \mathrm{P}$, with values of the same order as those recorded in our study. However, the dose-response effect was not significant in the study of Canova et al.
(1998) due to decreased levels or the absence of any effect at intermediate/higher $\mathrm{B}[\mathrm{a}] \mathrm{P}$ concentrations.

Significant dose-dependent differences were observed in each assay group for the effect of B[a]P on digestive gland 8-oxodGuo level. The level of 8-oxodGuo was increased from Day 10 in mussels exposed to $50 \mathrm{mg} \mathrm{B}[\mathrm{a}] \mathrm{P} \mathrm{kg}{ }^{-1}$ dry wt mussel $\mathrm{d}^{-1}$, whereas an increase was found at this date only in those exposed to a double $\mathrm{B}[\mathrm{a}] \mathrm{P}$ dose. In the former group, 8-oxodGuo levels followed a linear mathematical model with exposure time and $\mathrm{B}[\mathrm{a}] \mathrm{P}$ concentration, showing an increase in the extent of oxidative DNA damage and hence in the production of ROS. However, increase was only significant in this group for B[a]P mussel contents higher than $100 \mathrm{mg} \mathrm{kg}^{-1}$ dry wt mussel, which may represent an exposure level limit for the mussel in terms of its antioxidant and DNA repair abilities.

In animals exposed to a double dose of B[a]P, 8-oxodGuo levels were significantly higher at Day 10, but not at Day 21. At these times, B[a]P mussel content was respectively 240 and $428 \mathrm{mg} \mathrm{kg}^{-1}$ dry wt mussel. As induction of antioxidant activities apparently occurs as early as the first days of exposure (Akcha et al. 2000), a decrease in digestive gland 8-oxodGuo levels down to control values may be due to an induction of DNA repair mechanisms. As no decrease was observed in halfdosed mussels at Day 21 with a B[a]P mussel content of $340 \mathrm{mg} \mathrm{kg}^{-1}$ dry wt mussel, such an induction may coincide with an exposure level corresponding to a concentration in mussel greater than $340 \mathrm{mg} \mathrm{B}[\mathrm{a}] \mathrm{P} \mathrm{kg}^{-1}$ dry wt. This seems to be in accordance with the results obtained in mussel digestive gland DNA by Canova et al. (1998), which showed a dose-response increase in digestive gland 8-oxodGuo levels after $72 \mathrm{~h}$ exposure to concentrations ranging from 0 to $100 \mathrm{ppb} \mathrm{B}[\mathrm{a}] \mathrm{P}$ and decreased levels for higher concentrations $(500,1000 \mathrm{ppb})$ all leading to estimated $\mathrm{B}[\mathrm{a}] \mathrm{P}$ mussel contents greater than $387 \mathrm{mg} \mathrm{kg}^{-1}$ dry wt mussel.

In the present study, the decrease in 8-oxodGuo levels during depuration in mussels exposed to $50 \mathrm{mg} \mathrm{B}[\mathrm{a}] \mathrm{P}$ $\mathrm{kg}^{-1}$ dry wt mussel $\mathrm{d}^{-1}$ also suggested the existence of DNA repair mechanisms. Repair of DNA base oxidation, studied principally in Escherichia coli and Saccharomyces cerevisiae (Girard \& Boiteux 1997, Laval et al. 1998, Wang et al. 1998), mainly involves a base excision repair (BER) mechanism (Frosina et al. 1996). Although a similar mechanism has been identified in vertebrates (Demple \& Harrison 1994), nothing is known about base oxidation repair in marine invertebrates.

\section{Bulky B[a]P-related DNA adducts}

As previously demonstrated with our model, exposure of mussels to $\mathrm{B}[\mathrm{a}] \mathrm{P}$ led to induction of $\mathrm{B}[\mathrm{a}] \mathrm{P}$ - 
related adducts in gill DNA (Akcha et al. 1999). Although the present study confirmed the significant linear relationship between total DNA adduct level and both exposure time and whole mussel tissue $\mathrm{B}[\mathrm{a}] \mathrm{P}$ concentration, there were some differences concerning adduct levels and their pattern. In our previous experiment, 2 different adducts were induced in mussel gills after $28 \mathrm{~d}$ exposure to $50 \mathrm{mg}$ B[a]P $\mathrm{kg}^{-1}$ dry wt mussel $\mathrm{d}^{-1}$ (Akcha et al. in press). Whereas the first adduct appeared as early as Day 3, the second, more diffuse, one appeared later, from Day 24 of exposure. The maximal total DNA adduct level recorded at the end of the $28 \mathrm{~d}$ exposure period was $0.480 \pm$ $0.139 \mathrm{RAL} / 10^{8} \mathrm{dNps}$. In the present study, the number of adducts measured in gill DNA of mussels exposed to the same B[a]P dose was much greater, despite the fact that adduct induction was recorded only from Day 10 of exposure. Moreover, the adduct levels recorded were up to 10 times as high as those in our previous experiment, possibly because of the use of a different version of the ${ }^{32} \mathrm{P}$ post-labeling assay. In the present study, the use of a different DNA extraction protocol and of higher amounts of enzymes during the different steps of the post-labeling assay (digestion, enhancement, labeling) could have accounted for the better recovery of adducts quantitatively and qualitatively. The use of a different system of solvents for multidimensional chromatographic migration of samples certainly affected the migration of adducts, which may have been isolated in our previous experiment. Thus, adduct 1 and 2 in the present experiment could correspond to the 2 adducts previously described by us in mussels. Such difficulties in inter-study comparisons should be reduced by the intercalibration programs developed in recent years, e.g. the Biological Effects Quality Assurance in Monitoring Programs (BEQUALM).

The present study found no quantitative differences in total and individual adduct levels between the 2 tested doses of $\mathrm{B}[\mathrm{a}] \mathrm{P}$, possibly because of high standard deviation values of means obtained. The difference was not significant even at Day 3, when 3 out of the 6 adducts measured were only recorded in higherdosed mussels. Analysis of pooled rather than individual samples was not sufficient to prevent interindividual variability. In fact, inter-individual differences in filtration and metabolic activities may lead to high variability in absorption and $\mathrm{B}$ [a]P activation to DNA adducts. The high standard deviation values may also have been related to the method used for adduct quantification, justifying the reason why ${ }^{32} \mathrm{P}$ postlabeling assay is still considered as a semi-quantitative method.

The appearance of adducts respectively from Days 3 and 10 in mussels exposed to 100 and $50 \mathrm{mg} \mathrm{kg}^{-1}$ dry wt indicates that adduct formation was induced in mussels from a $\mathrm{B}[\mathrm{a}] \mathrm{P}$ exposure level corresponding to a $\mathrm{B}$ [a]P mussel content between 50 and $85 \mathrm{mg} \mathrm{B[a]P} \mathrm{kg}{ }^{-1}$ dry wt mussel. In the exposure conditions of our experiment, this concentration appears to be a limit beyond which phase II activities become insufficient to detoxify phase I B[a]P metabolites.

In both assay groups, the decrease in total DNA adduct level during depuration was not obvious, probably because of the high standard deviation values. However, as the decrease in adduct level during depuration was statistically significant at 1 time point (100 mg B[a]P kg-1 dry wt mussel d ${ }^{-1}$, Day 10 of depuration), it may be assumed that DNA adduct repair activities exist in mussels. This is consistent with the decrease observed during depuration in the $\left[{ }^{3} \mathrm{H}\right] \mathrm{B}[\mathrm{a}] \mathrm{P}$ binding value of mussel gill DNA (Akcha et al. 1999), and the work of Harvey \& Parry (1998), who reported the removal of 4-nitroquinoline 1-oxide DNA adducts in mussel digestive gland, gills and mantle during depuration. It is noteworthy in the present study that adduct removal appeared to be efficient during depuration, despite the observation that recovery from DNA damage did not occur to the same extent for the different B[a]P-induced DNA adducts. Although depuration allowed the elimination of some adducts, a few were still present in both groups at the end of the $10 \mathrm{~d}$ depuration period. A similar difference in the repair process has been reported in vertebrates for the major $\mathrm{B}[\mathrm{a}] \mathrm{P}$ bulky DNA adduct, BPDE-10-N² $\mathrm{N}$, with preferential repair involving the trans isoform (Celotti et al. 1993, Jernström \& Gräslund 1994). Although bulky DNA adducts in vertebrates have been demonstrated to be repaired by both the nucleotide/base excision and the DNA mismatch repair systems, the mechanisms involved in mussels have not yet been elucidated.

The differences in the adduct repair process noted in the present study have important implications for biomonitoring of the marine environment. The use of DNA adducts as biomarkers of past exposure to genotoxic compounds depends on their persistence and thus on their repair ability in mussels, which is thought to be highly dependent on their chemical structure.

The results reported here, like those in our previous experiment, indicate that $\mathrm{B}[\mathrm{a}] \mathrm{P}$ absorbed by mussels is biotransformed into electrophilic metabolites that bind covalently to DNA. As adduct standards were not used in this post-labeling experiment, the B[a]P activation pathways could not be identified. The existence of an epoxide hydrolase activity and the identification of $\mathrm{B}$ [a]P-dihydrodiols as relevant in vivo $\mathrm{B}[\mathrm{a}] \mathrm{P}$ metabolites in mussels justify the suspicion of a vertebrate-like diol-epoxide pathway (Sims et al. 1974, Grover 1986). This assumption is supported by the identification, in vitro and in vivo, in mussels of an adduct presenting 
high chromatographic similarities with BPDE-10- $\mathrm{N}^{2} \mathrm{dG}$ by the butanol-enhanced ${ }^{32} \mathrm{P}$ post-labeling assay (Harvey \& Parry 1997). However, recent results of Ross et al. (1999) demonstrated that B[a]P-related DNA adducts in mussels result from covalent binding of 4,5-B[a]P oxide to guanine and adenine.

\section{Conclusion}

An increase in digestive gland 8-oxodGuo and induction of gill DNA adduct levels were recorded for $\mathrm{B}[\mathrm{a}] \mathrm{P}$ exposure levels corresponding respectively to an internal mussel content of around 100 and $50 \mathrm{mg} \mathrm{kg}^{-1}$ dry wt mussel. As B[a]P is one of the most genotoxic PAHs, these limits will be higher when converted into the commonly measured total PAH concentration. Taking into account the environmentally reported PAH concentration in mussels (Claisse 1989, AmodioCocchieri et al. 1993, RNO 1995), this raises the question of whether such damage could possibly be observed in the field. Despite the DNA adduct formation reported in PAH-environmentally exposed mussels (Solé et al. 1996, Venier et al. 1996), a lack of adduct identification has never led to the incrimination of this class of pollutants. Thus, the feasibility of using DNA adducts as biomarkers of PAH genotoxicity in mussels will require further study.

With our model, the exposure of mussels to a lower dose of a common PAH mixture might allow a better evaluation of the potential use of both DNA adducts and 8-oxodGuo for mussel-based biomonitoring of the marine environment. As a fraction of feed-incorporated $\mathrm{B}[\mathrm{a}] \mathrm{P}$ may desorb to the water-column, it would also seem important to study the possible effect of this process.

Acknowledgements. This work was supported by the IFREMER (French Research Institute for Exploitation of the Sea) and a European BIOMAR program (ENV5-CT96-0300). The authors are grateful to Karyn Le Ménach for GC/MS analysis.

\section{LITERATURE CITED}

Akcha F, Burgeot T, Venier P, Narbonne JF (1999) Relationship between kinetics of benzo[a]pyrene bioaccumulation and DNA binding in the mussel Mytilus galloprovincialis. Bull Environ Contam Toxicol 62:455-462

Akcha F, Izuel C, Venier P, Budzinski H, Burgeot T, Narbonne JF (2000) Enzymatic biomarker measurement and study of DNA adduct formation in B[a]P-contaminated mussels, Mytilus galloprovincialis. Aquat Toxicol 49:269-287

Akcha F, Ruiz S, Zampieron C, Venier P, Burgeot T, Cadet J, Narbonne JF (in press) Benzo[a]pyrene-induced DNA damage in Mytilus galloprovincialis. Measurement of bulky DNA adducts and DNA oxidative damage in terms of 8-oxo-7, 8-dihydro-2'-deoxyguanosine. Biomarkers
Amodio-Cocchieri R, Del Prete U, Arnese A, Giuliano M, Roncioni A (1993) Heavy metals and polycyclic aromatic hydrocarbons (PAH's) in marine organisms from the Ionian Sea (Italy). Bull Environ Contam Toxicol 50: $618-625$

Auffret M (1988) Histopathological changes related to chemical contamination in Mytilus edulis from field and experimental conditions. Mar Ecol Prog Ser 46:101-107

Barrett JC (1992) Mechanisms of action of known human carcinogens. In: Vainio $\mathrm{H}$, Magee PN, McGregor DB, McMichael AJ (eds) Mechanisms of carcinogenesis in risk assessment. International Agency for Cancer Research, Lyon, p 115-134

Björk M, Gilek M (1996) Uptake and elimination of ${ }^{14} \mathrm{C}$ phenanthrene by the blue mussel Mytilus edulis L. at different algal concentrations. Bull Environ Contam Toxicol 56:151-158

Cadet J, Berger M, Douki T, Ravanat JL (1997) Oxidative damage to DNA: formation, measurement and biological significance. Rev Physiol Biochem Pharmacol 31:1-87

Canova S, Degan P, Peters LD, Livingstone DR, Voltan R, Venier P (1998) Tissue dose, DNA adducts, oxidative DNA damage and CYP1A-immunopositive proteins in mussels exposed to waterborne benzo[a]pyrene. Mutat Res 399: $17-30$

Celotti L, Ferraro P, Furlan D, Zanesi N, Pavanello S (1993) DNA repair in human lymphocytes treated in vitro with $( \pm)$-anti and $( \pm)$-syn-benzo[a]pyrene diolepoxide. Mutat Res 294:117-126

Chen L, Devanesan PD, Higginbotham S, Ariese F, Jankowiak R, Small GJ, Rogan EG, Cavalieri EL (1996) Expanded analysis of benzo[a]pyrene-DNA adducts formed in vitro and in mouse skin: their significance in tumor initiation. Chem Res Toxicol 9:897-903

Cheng KC, Cahill DS, Kasai H, Nishimura S, Loeb LA (1992) 8-hydroxyguanine, an abundant form of oxidative DNA damage, causes $\mathrm{G} \rightarrow \mathrm{T}$ and $\mathrm{A} \rightarrow \mathrm{C}$ substitutions. J Biol Chem 267:166-172

Claisse D (1989) Chemical contamination of French coasts. Baseline 20:523-528

Colapietro AM, Goodell AL, Smart RC (1993) Characterization of benzo[a]pyrene-initiated mouse skin papillomas for Ha-ras mutations and protein kinase C levels. Carcinogenesis 14:2289-2295

Demple B, Harrison L (1994) Repair of oxidative damage to DNA: enzymology and biology. Annu Rev Biochem 63: 915-948

De Vries A, Dollé MET, Broekhof JLM, Muller JJA, Dinant Kroese E, Van Kreijl CF, Capel PJA, Vijg J, Van Steeg H (1997) Induction of DNA adducts and mutations in spleen, liver and lung of XPA-deficient/lac Z transgenic mice after oral treatment with benzo[a]pyrene: correlation with tumor development. Carcinogenesis 18:2327-2332

Dunn BP, Stich HF (1976) Release of carcinogen benzo(a)pyrene from environmentally contaminated mussels. Bull Environ Contam Toxicol 15:398-401

Eertman RHM, Groenink CLFMG, Sandee B, Hummel H (1995) Response of the blue mussel Mytilus edulis L. following exposure to PAHs or contaminated sediment. Mar Environ Res 39:169-173

Fong AT, Dashwood RH, Cheng R, Mathews C, Ford B, Hendricks JD, Bailey GS (1993) Carcinogenicity, metabolism and Ki-ras proto-oncogene activation by 7-12-dimethylbenz[a]anthracene in rainbow trout. Carcinogenesis 14: 629-635

Frosina G, Fortini P, Rossi O, Carrozzino F, Raspaglio G, Cox LS, Lane DP, Abbondandolo A, Dogliotti E (1996) Two 
pathways for base excision repair in mammalian cells. J Biol Chem 271:9573-9578

Garcia Martinez P, Livingstone DR (1995) Benzo[a]pyrenedione-stimulated oxyradical production by microsomes of digestive gland of the common mussel, Mytilus edulis L. Mar Environ Res 39:185-189

Garcia Martinez P, Winston GW, Metosh-Dickey C, O'Hara SCM, Livingstone DR (1995) Nitrofurantoin-stimulated reactive oxygen species production and genotoxicity in digestive gland microsomes and cytosol of the common mussel (Mytilus edulis L.). Toxicol Appl Pharmacol 131: $332-341$

Gardner GR (1993) Chemically induced histopathology in aquatic invertebrates. In: Couch JA, Fournie JW (eds) Pathobiology of marine and estuarine organisms, CRC Press, Boca Raton, p 359-391

Gardner GR, Yevich PP, Harshbarger JC, Malcom AR (1991) Carcinogenicity of Black Rock Harbor, Bridgeport, CT, sediment to the eastern oyster and trophic transfer of Black Rock Harbor carcinogens from the blue mussel to the winter flounder. J Environ Health Perspect 90:53-66

Gardner GR, Pruell RJ, Malcolm AR (1992) Chemical induction of tumors in oysters by a mixture of aromatic and chlorinated hydrocarbons, amines and metals. Mar Environ Res 34:59-63

Genevois C, Pfohl-Leszkowicz A, Boillot K, Brandt H, Castegnaro $M$ (1998) Implication of Cytochrome P450 1A isoforms and the Ah receptor in the genotoxicity of coal-tar fume condensate and bitume fumes condensates. Environ Toxicol Pharmacol 5:283-294

Girard PM, Boiteux S (1997) Repair of oxidized DNA bases in the yeast Saccharomyces cerevisiae. Biochimie 79: 559-566

Goldberg ED (1975) The mussel watch. A first step in global marine biomonitoring. Mar Pollut Bull 6:111

Grover PL (1986) Pathways involved in the metabolism and activation of polycyclic hydrocarbons. Xenobiotica 16: 915-931

Harvey JS, Parry JM (1997) The detection of genotoxininduced DNA adducts in the common mussel Mytilus edulis. Mutagenesis 12:153-158

Harvey JS, Parry JM (1998) The analysis of DNA adduct formation, removal and persistence in the common mussel Mytilus edulis exposed to 4-nitroquinoline 1-oxide. Mutat Res 399:31-42

Helbock HJ, Beckman KB, Shigenaga MK, Walter PB, Woodall AA, Yeo HC, Ames BN (1998) DNA oxidation matters: the HPLC-electrochemical detection assay of 8-oxo-deoxyguanosine and 8-oxo-guanine. Proc Natl Acad Sci USA 95:288-293

Hendricks JD, Meyers TR, Shelton DW, Casteel JL, Bailey GS (1985) Hepatocarcinogenicity of benzo[a]pyrene to rainbow trout by dietary exposure and intraperitoneal injection. J Natl Cancer Inst 74:839-851

Jelinsky SA, Liu T, Geacintov NE, Loechler EL (1995) The major, $N^{2}$-Gua adduct of the $(+)$-anti diol epoxide is capable of inducing $\mathrm{G} \rightarrow \mathrm{A}$ and $\mathrm{G} \rightarrow \mathrm{C}$, in addition to $\mathrm{G} \rightarrow \mathrm{T}$, mutations. Biochemistry 34:13545-13553

Jernström B, Gräslund A (1994) Covalent binding of benzo[a]pyrene 7,8-dihydrodiol 9,10-epoxides to DNA: molecular structures, induced mutations and biological consequences. Biophys Chem 49:185-199

Kuchino Y, Mori F, Kasai H, Inoue H, Iwai S, Miura K, Ohtsuka E, Nishimura S (1987) Misreading of DNA templates containing 8-hydroxydeoxyguanosine at the modified base and at adjacent residues. Nature 327:77-79

La DK, Swenberg JA (1996) DNA adducts: biological markers of exposure and potential applications to risk assessment Mutat Res 365:129-146

Landahl JT, McCain BB, Myers MS, Rhodes LT, Brown DW (1990) Consistent associations between hepatic lesions in English sole (Parophrys vetulus) and polycyclic aromatic hydrocarbons in sediment. Environ Health Perspect 89: 195-203

La Rocca C, Conti L, Crebelli R, Crochi B, Iacovella N, Rodriguez F, Turrio-Baldassarri L, Di Domenico A (1996) PAH content and mutagenicity of marine sediments from the Venice lagoon. Ecotoxicol Environ Saf 33:236-245

Laval J, Jurado J, Saparbaev M, Sidorkina O (1998) Antimutagenic role of base-excision repair enzymes upon free radical-induced DNA damage. Mutat Res 402:93-102

Livingstone DR (1991) Organic xenobiotic metabolism in marine invertebrates. In: Gilles DR (ed) Advances in comparative and environmental physiology. Springer-Verlag, Berlin, p 45-185

Livingstone DR, Pipe RK (1992) Mussels and environmental contaminants: molecular and cellular aspects. In: Grosling E (ed) The mussel, Mytilus edulis: ecology, physiology, genetics and culture. Elsevier, Amsterdam, p 425-464

Livingstone DR, Garcia Martinez P, Winston GW (1989) Menadione-stimulated oxyradical formation in digestive gland microsomes of the common mussel, Mytilus edulis L. Aquat Toxicol 15:213-236

Livingstone DR, Garcia Martinez P, Michel X, Narbonne JF, O'Hara S, Ribera D, Winston GW (1990) Oxyradical production as a pollution-mediated mechanism of toxicity in the common mussel, Mytilus edulis L., and other mollusks. Funct Ecol 4:415-424

MacMahon G, Huber LJ, Moore MJ, Stegeman JJ, Wogan GN (1990) Mutations in c-Ki-ras oncogenes in diseased livers of winter flounder from Boston harbor. Proc Natl Acad Sci USA 87:841-845

Michel P (1983) Dosage global des hydrocarbures aromatiques dans les organismes marins par CLHP-fluorescence. In: Aminot A, Chaussepied M (eds) Manuel des analyses chimiques en milieu marin, CNEXO, Paris, p 337-346

Michel XR, Suteau P, Robertson LW, Narbonne JF (1993) Effects of benzo(a)pyrene, 3, 3', 4, 4', 5, 5'-hexachlorobiphenyl on the xenobiotic-metabolizing enzymes in the mussel (Mytilus galloprovincialis). Aquat Toxicol 27:335-344

Michel XR, Beasse C, Narbonne JF (1995) In vivo metabolism of benzo(a)pyrene in the mussel Mytilus galloprovincialis. Arch Environ Contam Toxicol 28:215-222

Mitchelmore CL, Chipman JK (1998) DNA strand breakage in aquatic organisms and the potential value of the comet assay in environmental monitoring. Mutat Res 399:135-147

Mix MC, Schaffer RL, Hemingway SJ (1981) Polynuclear aromatic hydrocarbons in bay mussels (Mytilus edulis) from Oregon. In: Dawe CJ et al. (eds) Phyletic approaches to cancer. Japan Sci Soc Press, Tokyo, p 167-177

Moore MN (1988) Cytochemical responses of the lysosomal system and NADPH-ferriprotein reductase in molluskan digestive gland cells to environmental and experimental exposure to xenobiotics. Mar Ecol Prog Ser 46:37-43

Moy FE, Walday M (1996) Accumulation and depuration of organic micro-pollutants in marine hard bottom organisms. Mar Pollut Bull 33:56-63

Myers MS, Stehr CM, Olson OP, Johnson LL, McCain BB, Chan SL, Varanasi U (1994) Relationship between toxicopathic hepatic lesions and exposure to chemical contaminants in English sole (Pleuronectes vetulus), starry flounder (Platichthys stellatus), and white croaker (Genyonemus lineatus) from selected marine sites on the Pacific coast, USA. Environ Health Perspect 102:200-214 
Narbonne JF, Ribera D, Garrigues P, Lafaurie M, Romana A (1992) Different pathways for the uptake of benzo(a)pyrene adsorbed to sediment by the mussel Mytilus galloprovincialis. Bull Environ Contam Toxicol 49:150-156

Neff JM (1984) Bioaccumulation of organic micropollutants from sediments and suspended particulates by aquatic animals. Fresenius Z Anal Chem 319:132-136

Penry DL, Weston DP (1998) Digestive determinants of benzo[a]pyrene and phenanthrene bioaccumulation by a deposit-feeding polychaete. Environ Toxicol Chem 17: 2254-2265

Regoli F (1998) Trace metals and antioxidant enzymes in gills and digestive gland of the Mediterranean mussel Mytilus galloprovincialis. Arch Environ Contam Toxicol 34:48-63

Ribera D, Narbonne JF, Michel X, Livingstone DR, O'Hara S (1991) Responses of antioxidants and lipid peroxidation in mussels to oxidative damage exposure. Comp Biochem Physiol 100C:177-181

RNO (1995) Le RNO: surveillance du milieu marin. IFREMER et Ministère de l'environnement, Paris

Ross JA, Nelson GB, Zampieron C, Venier P (1999) Benzo[a]pyrene-DNA adducts in Mytilus galloprovincialis result from K-region oxidation. 17th International Symposium on Polycyclic Aromatic Compounds, October 25-29, Bordeaux

Shigenaga MK, Ames BN (1991) Assays for 8-hydroxy-2'deoxyguanosine: a biomarker of in vivo oxidative DNA damage. Free Radical Biol Med 10:211-216

Shukla R, Geacintov NF, Loechler FL (1999) The major, N2$\mathrm{dG}$ adduct of $(+)$-anti-B[a]PDE induces $\mathrm{G} \rightarrow \mathrm{A}$ mutations in a $5^{\prime}$-AGA-3' sequence context. Carcinogenesis 20: 261-268

Simic MG (1994) DNA markers of oxidative processes in vivo: relevance to carcinogenesis and anticarcinogenesis. Cancer Res 54:1918-1923

Sims P, Grover PL, Swaisland A, Pal K, Hewer A (1974)

Editorial responsibility: Otto Kinne (Editor), Oldendorf/Luhe, Germany
Metabolic activation of Benzo(a)pyrene proceeds by a diol epoxide. Nature 252:326-328

Sjölin AM, Livingstone DR (1997) Redox cycling of aromatic hydrocarbon quinones catalyzed by digestive gland microsomes of the common mussel (Mytilus edulis L.). Aquat Toxicol 38:83-99

Solé M, Porte C, Albaigès J (1994) Mixed-function oxygenase system components and antioxidant enzymes in different marine bivalves: its relation with contaminant body burdens. Aquat Toxicol 30:271-283

Solé M, Porte C, Biosca X, Mitchelmore CL, Chipman JK, Livingstone DR, Albaigès J (1996) Effects of the 'Aegean Sea' oil spill on biotransformation enzymes, oxidative stress and DNA-adducts in digestive gland of the mussel ( $M Y$ tilus edulis L.). Comp Biochem Physiol 113C:257-265

Stegeman JJ (1985) Benzo[a]pyrene oxidation and microsomal enzyme activity in the mussel (Mytilus edulis) and other bivalve mollusk species from the Western North Atlantic. Mar Biol 89:21-30

Venier P, Canova S, Levis AG (1996) DNA adducts in Mytilus galloprovincialis and Zosterisessor ophiocephalus collected from PAC-polluted and reference sites of the Venice Lagoon. Pol Arom Comp 11:67-73

Viarengo A, Canesi L (1991) Mussels as biological indicators of pollution. Aquaculture 94:225-243

Wang D, Kreutzer DA, Essigmann JM (1998) Mutagenicity and repair of oxidative DNA damage: insights from studies using defined lesions. Mutat Res 400:99-115

Wirgin I, Currie D, Garte SJ (1989) Activation of the K-ras oncogene in liver tumors of Hudson River tomcod. Carcinogenesis 10:2311-2315

Yevich PP, Yevich C, Pesch G (1987) Effects of Black Rock Harbor dredged material on the histopathology of the blue mussel Mytilus edulis and polychaete worm Nephtys incisa after laboratory and field exposures. US EPA Technical Report D-87-8, Narragansett, RI

Submitted: December 3, 1999; Accepted: March 24, 2000

Proofs received from author(s): September 27, 2000 